\title{
PERAN TOKOH AGAMA UNTUK MENCEGAH DAN MENANGGULANGI STUNTING
} [THE ROLE OF RELIGIOUS CHARACTERS TO PREVENT AND OVERCOME STUNTING]

\author{
Henry S. Imbar, Nita R. Momongan \\ Poltekkes Kemekes Manado Jurusan Gizi, Indonesia \\ hnrmbr@gmail.com \\ DOI :10.47718/jpd.v8i02.1194
}

\section{ABSTRAK}

ABSTRAK 


\section{ABSTRACT}

Background The development of nutrition problems in Indonesia is getting more complex nowadays. Apart from still facing the problem of malnutrition, the problem of excess nutrition is also a problem that we must deal with seriously. Indonesia is a country with the prevalence of stunting fifth largest in the world. To achieve optimal growth and development, WHO / UNICEF recommends four important things that must be done, one of which is exclusive breastfeeding. Community empowerment through religious leaders is an alternative to increase knowledge and attitudes and to help breastfeeding mothers succeed.

The purpose of study was to determine the differences in stunting status of infants whose mothers received guidance / counseling from religious leaders from pregnancy to breastfeeding for up to two months in South Minahasa Regency. This type of research is a research Quasi Experiment, while the research design is a pre post test control group. The number of samples of the study was 84 pregnant women divided into two groups, namely the group given counseling by religious leaders totaling 42 pregnant women and 42 pregnant women who did not receive counseling. The results of the T-statistical analysis test with a confidence level of 95\%, found no significant difference in weight gain based on KMS between the treatment and control groups $(P=0.248)$ and there was no difference in the percentage of weight gain between the treatment and control groups $(P=0.297)$.

The conclusion in this study is that there are no significant differences in knowledge, attitudes, and weight gain in the treatment and control groups, there are significant differences in exclusive breastfeeding behavior in the treatment group and the control group, and there is a significant difference between weight gain based on KMS and exclusive breastfeeding behavior.

Keywords: Religious Leaders; Exclusive Breastfeeding Behavior; Infant Stunting Status

Perkembangan masalah gizi di Indonesia semakin kompleks saat ini, selain masih menghadapi masalah kekurangan gizi, masalah kelebihan gizi juga menjadi persoalan yang harus kita tangani dengan serius. Hasil Riset Kesehatan Dasar (Riskesdas) 
tahun 2018 menunjukkan angka stanting anak Balita di Indonesia yaitu 30,8\% dan di seluruh dunia, Indonesia adalah negara dengan prevalensi stunting kelima terbesar. Beberapa penyebab terjadinyanya masalah stunting yaitu ketahanan pangan terkait dengan makanan bergizi dan linkungan sosial yang terkait dengan praktik pemberian makanan dan pola pengasuhan anak, oleh karenanya diperlukan rencana intervensi yang komprehensif untuk dapat mengurangi pervalensi stunting di Indonesia. Faktor pemenuhan zat gizi memegang peranan penting dalam siklus hidup manusia. Kekurangan zat gizi pada ibu hamil dapat menyebabkan Bayi Berat Lahir Rendah (BBLR) dan penurunan tingkat kecerdasan. Pada bayi dan anak, kekurangan gizi akan menimbulkan gangguan pertumbuhan dan perkembangan yang apabila tidak diatasi secara dini dapat berlanjut hingga dewasa. Usia 0-24 bulan merupakan masa pertumbuhan dan perkembangan yang pesat, sehingga kerap diistilahkan sebagai periode emas sekaligus periode kritis. Periode emas dapat diwujudkan apabila pada masa ini bayi dan anak memperoleh asupan gizi yang sesuai untuk tumbuh kembang optimal. Sebaliknya apabila bayi dan anak pada masa ini tidak memperoleh makanan sesuai kebutuhan gizinya, maka periode emas akan berubah menjadi periode kritis yang akan mengganggu tumbuh kembang bayi dan anak, baik pada saat ini maupun masa 
selanjutnya (Pritasari,dkk.2017). Berbagai program terkait pencegahan stunting telah diselenggarakan, namun belum efektif dan belum terjadi dalam skala yang memadai. Kajian bank Dunia dan Kementerian Kesehatan Indonesia menemukan bahwa sebagaian besar ibu hamil dan anak berusia di bawah dua tahun tidak memiliki akses memadai terhadap layanan dasar, sementara tumbuh kembang anak sangat tergantung pada akses terhadap intervensi gizi spesifik dan sensitif, teriutama selama 1.000 hari pertama kehidupan. Pendekatan intervensi gizi yang terpadu atau konvergen sangat penting dilakukan untuk mencegah stunting dan masalah gizi (Sekretariat Wapres R.I, 2019). Pemberdayaan masyarakat melalui tokoh agama merupakan salah satu alternatif untuk meningkatkan pengetahuan dan sikap serta membantu keberhasilan ibu menyusui.

\section{METODE PENELITIAN}


bisa membaca dan menulis serta bersedia ikut dalam penelitian. Pelaksana bimbingan adalah peneliti dan orang tokoh agama (Pendeta dan guru agama) yang sudah dilatih. Materi bimbingan adalah berdasarkan materi pada modul manajemen laktasi, yang diterbitkan oleh Kementerian Kesehatan yang mengacu pada modul WHO/UNICEF yang dimodifikasi oleh peneliti. Proses bimbingan yaitu subjek yang berkunjung di Puskesmas atau klinik bersalin diberikan konseling oleh tokoh agama baik secara langsung dan atau melalui telepon. Konseling melalui telpon dilakukan karena waktu penelitian berlangsung pada masa pandemi Covid-19. Subjek yang tidak berkunjung di Puskesmas atau klinik bersalin, diberikan konseling individu di rumah subjek dan atau melalui telepon. Bimbingan dilakukan sebanyak empat kali yaitu : 1) saat hamil (kunjungan pertama); 2). hamil (kunjungan kedua); 3). satu bulan setelah konseling ke dua (melahirkan); dan 4). satu bulan setelah konseling ketiga. Pelaksanaan bimbingan dilakukan secara bertahap, yaitu tahap pencairan, tahap penjelasan dan tahap pemecahan masalah. Lama konseling setiap subjek adalah sekitar 5-10 menit dan dilaksanakan di dalam ruangan dan atau melalui telepon. Untuk meningkatkan pemahaman subjek terhadap materi konseling, dilakukan tanya jawab antara konselor dengan subjek. Penelitian dilaksanakan selama enam bulan pada tahun 2019. Variabel penelitian pada model 1 terdiri dari variabel bebas, 
HASIL DAN PEMBAHASAN yaitu bimbingan tokoh agama dan variable terikat yaitu perilaku menyusui eksklusif dan status stunting bayi. Variabel penelitian pada model 2 terdiri dari variabel bebas, yaitu bimbingan tokoh agama dan perilaku menyusui eksklusif, sementara variable terikat yaitu status stunting bayi. Instrument penelitian menggunakan kuesioner, form recall 24 jam untuk mengukur perilaku menyusui eksklusif bayi, modul manajemen laktasi, alat ukur antropometri untuk mengukur berat dan tinggi badan, serta alat tulis menulis dan komputer. Analisa data menggunakan uji T.

\section{Tabel 1.}

Pengaruh Konseling Terhadap Pengetahuan Responden tentang Menyusui dan Kesehatan Ibu dan Bayi

\begin{tabular}{|c|c|c|c|c|c|c|c|c|}
\hline \multirow{3}{*}{ No } & \multirow{3}{*}{$\begin{array}{l}\text { Penge- } \\
\text { tahuan }\end{array}$} & \multicolumn{4}{|c|}{ Kelompok } & \multicolumn{2}{|c|}{ Jumlah } & \multirow{3}{*}{$\begin{array}{c}\text { Nilai } \\
\text { P }\end{array}$} \\
\hline & & \multicolumn{2}{|c|}{ Perlakuan } & \multicolumn{2}{|c|}{ Kontrol } & & llah & \\
\hline & & $\mathrm{n}$ & $\%$ & $\mathrm{n}$ & $\%$ & $\mathrm{n}$ & $\%$ & \\
\hline \multirow[t]{2}{*}{1.} & Baik & 36 & 48,4 & 35 & 46,9 & 71 & 84,5 & \\
\hline & & & & & & 12 & & 0,55 \\
\hline 2. & Jumlah & 2 & 50 & 2 & (1) & 81 & 10,0 & \\
\hline
\end{tabular}

Uji statistik $\chi 2$ menunjukan tidak ada perbedaan yang bermakna tentang pengetahuan antara kelompok perlakuan dan kontrol $(\mathrm{P}=$ $0,055)$. Pengetahuan subjek tentang menyusui dan kesehatan ibu dan bayi yang mendapat koseling dan tidak mendapat koseling tidak berbeda. 
Tabel 2.

Perbedaan Sikap Untuk Menyusui Eksklusif Ibu Yang Diberikan Konseling Dan Tidak Diberikan Konseling

\begin{tabular}{|c|c|c|c|c|c|c|c|c|}
\hline \multirow{3}{*}{ No } & \multirow{3}{*}{ Sikap } & \multicolumn{4}{|c|}{ Kelompok } & \multirow{2}{*}{\multicolumn{2}{|c|}{ Jumlah }} & \multirow{3}{*}{ Nilai P } \\
\hline & & \multicolumn{2}{|c|}{ Perlakuan } & \multicolumn{2}{|c|}{ Kontrol } & & & \\
\hline & & $n$ & $\%$ & $\mathrm{n}$ & $\%$ & $\mathrm{n}$ & $\%$ & \\
\hline \multirow[t]{2}{*}{1.} & Sangat & 18 & 20,3 & 11 & 9,4 & 29 & 29,7 & \\
\hline & mendukung & & & & & & & 0,055 \\
\hline \multirow[t]{2}{*}{2.} & Mendukung & 24 & 29,7 & 31 & 40,6 & 55 & 70,3 & \\
\hline & Jumlah & 42 & 50,0 & 42 & 50,0 & 84 & 100 & \\
\hline
\end{tabular}

Sesuai hasil analisis statistik, penulis tidak melihat adanya perbedaan yang bermakna tentang pengetahuan maupun sikap subjek antara kelompok perlakuan dengan control $(P=0,055)$. Sikap subjek untuk menyusui secara eksklusif pada ibu yang mendapat koseling dan tidak mendapat koseling tidak berbeda.

Tabel 3. Perbedaan Perilaku Menyusui Eksklusif Ibu Yang Diberikan Konseling Dan Tidak Diberikan Konseling

\begin{tabular}{|c|c|c|c|c|c|c|c|c|}
\hline \multirow{3}{*}{ No } & \multirow{3}{*}{$\begin{array}{c}\text { Perilaku } \\
\text { menyusui } \\
\text { eksklusif }\end{array}$} & \multicolumn{4}{|c|}{ Kelompok } & \multirow{2}{*}{\multicolumn{2}{|c|}{ Jumlah }} & \multirow{3}{*}{$\begin{array}{c}\text { Nilai } \\
\text { P }\end{array}$} \\
\hline & & \multicolumn{2}{|c|}{ Perlakuan } & \multicolumn{2}{|c|}{ Kontrol } & & & \\
\hline & & $\mathrm{n}$ & $\%$ & $\mathrm{n}$ & $\%$ & $\mathrm{n}$ & $\%$ & \\
\hline 1. & 4 bulan & 30 & 39,1 & 18 & 20,3 & 48 & 57,1 & 0,002 \\
\hline \multirow[t]{2}{*}{2.} & $<4$ bulan & 12 & 10,9 & 24 & 29,7 & 36 & 42,9 & \\
\hline & Jumlah & 42 & 50,0 & 42 & 50,0 & 84 & 100 & \\
\hline
\end{tabular}

Tabel 3 menunjukan bahwa subjek yang diberikan konseling menyusui cakupan menyusui eksklusif lebih baik dibandingkan kelompok kontrol. Pemberian intervensi konseling pada kelompok perlakuan dapat meningkatkan perilaku menyusui eksklusif sekitar $20 \%$. 
Tabel 4. Perbedaan Pertumbuhan Bayi Darilbu Yang Diberikan Konseling Dan Tidak Diberikan Konseling

\begin{tabular}{|c|c|c|c|c|c|c|c|c|}
\hline \multirow{3}{*}{ No } & \multirow{3}{*}{$\begin{array}{l}\text { Pertum } \\
\text { buhan } \\
\text { berat } \\
\text { badan }\end{array}$} & \multicolumn{4}{|c|}{ Kelompok } & & & \multirow{3}{*}{ Nilai P } \\
\hline & & \multicolumn{2}{|c|}{ Perlakuan } & \multicolumn{2}{|c|}{ Kontrol } & \multicolumn{2}{|c|}{ Jumlah } & \\
\hline & & $\mathrm{n}$ & $\%$ & $\mathrm{n}$ & $\%$ & $\mathrm{n}$ & $\%$ & \\
\hline 1. & Naik & 31 & 40,6 & 27 & 34,4 & 58 & 69 & \multirow{3}{*}{0,248} \\
\hline \multirow[t]{2}{*}{2.} & Tidak naik & 11 & 9,4 & 15 & 15,6 & 26 & 31 & \\
\hline & Jumlah & 42 & 50,0 & 42 & 50,0 & 84 & 100 & \\
\hline
\end{tabular}

Tabel 4 menunjukkan menunjukan tidak ada perbedaan perbedaan persentase penambahan berat badan antara kelompok perlakuan dan kontrol ( $P=0,297)$. Pertumbuhan berat badan bayi dari ibu yang mendapat koseling dan tidak mendapat koseling tidak berbeda.

Tabel 5. Perbedaan Persentase Penambahan Berat Badan, Panjang Badan, dan LLA Bayi Dari Ibu Yang Diberikan Konseling Dan Tidak Diberikan Konseling

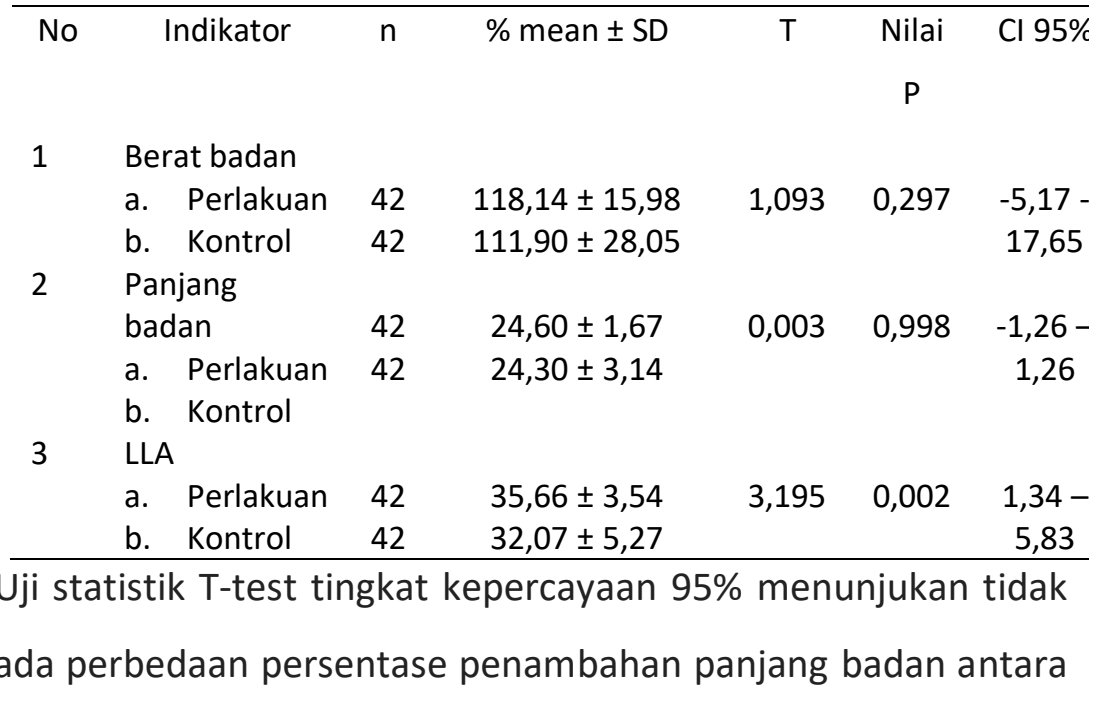


kelompok perlakuan dan kontrol $(P=0,998)$.

Uji statistik T-test dengan tingkat kepercayaan 95\% menunjukan ada perbedaan bermakna tentang persentase penambahan LLA antara kelompok perlakuan dan kontrol $(\mathrm{P}=$ $0,002)$.

Tabel 6.

Perbedaan Pertumbuhan Berdasarkan KMS Bayi Yang Menyusi Ekslusif 4 Bulan dan Kurang dari 4 Bulan

\begin{tabular}{|c|c|c|c|c|c|c|c|c|}
\hline \multirow{4}{*}{ No } & \multirow{4}{*}{$\begin{array}{l}\text { Pertum- } \\
\text { buhan } \\
\text { berat } \\
\text { badan }\end{array}$} & \multicolumn{4}{|c|}{ Perilaku menyusui } & & & \multirow{4}{*}{ Nilai P } \\
\hline & & \multirow{2}{*}{\multicolumn{2}{|c|}{$\begin{array}{c}\text { Eksklusif } 4 \\
\text { bulan }\end{array}$}} & \multirow{2}{*}{\multicolumn{2}{|c|}{$\begin{array}{c}\text { Eksklusif <4 } \\
\text { bulan }\end{array}$}} & \multicolumn{2}{|c|}{ Jumlah } & \\
\hline & & & & & & \multirow[t]{2}{*}{$\mathrm{n}$} & \multirow[t]{2}{*}{$\%$} & \\
\hline & & $\mathrm{n}$ & $\%$ & $\mathrm{n}$ & $\%$ & & & \\
\hline 1. & Naik & 39 & 53,1 & 19 & 21,9 & 58 & 69 & 0,001 \\
\hline \multirow[t]{2}{*}{2.} & $\begin{array}{l}\text { Tidak } \\
\text { naik }\end{array}$ & 9 & 6,3 & 17 & 18,8 & 26 & 31 & \\
\hline & Jumlah & 48 & 59,4 & 36 & 40,6 & 84 & 100 & \\
\hline
\end{tabular}

Uji statistik T-test menunjukan ada perbedaan yang bermakna persentase penambahan berat badan antara bayi yang menyusu eksklusif 4 bulan dan kurang dari 4 bulan $(P=0,001)$.

\section{PEMBAHASAN}

Hasil analisa data pengaruh konseling terhadap pengetahuan dan sikap tentang menyusui dan kesehatan ibu dan bayi menunjukkan tidak ada perbedaan bermakna. Pengetahuan subjek tentang menyusui dan kesehatan ibu dan bayi tidak berbeda antara responden yang mendapat koseling dan responden tidak mendapat koseling. 
Pengaruh intervensi terhadap pengetahuan yang tidak berbeda bermakna ditemukan juga pada penelitian Harahap (2000). Metode intervensi yang digunakan sama dengan metode pada peneltian ini yaitu konseling dan rancangan penelitiannya adalah kuasi eksperimen.

Hal ini berbeda dengan hasil penelitian Ambarwati,Ria dkk (2013) tentang pengaruh konseling laktasi intensif terhadap pemberian ASI, dimana kelompok tanpa penyuluhan laktasi intensif menunjukkan tidak adanya peningkatan pengetahuan, dan siikap terhadap inisiasi menyusui dini, ASI ekslusif, dan tidak ada peningkatan jumlah pemberian ASI ekslusif pada bayinya. Sementara kelompok yang diberikan penyuluhan ASI secara intensif menunjukkan peningkatan pengetahuan yang signifikan sikap positif terhadap inisiasi menyusu dini, pemberian ASI eksklusif, ASI eksklusif dan peningkatan signifikan jumlah pemberian ASI Eksklusif selama 3 bulan pada bayi yang lahir sebelum dan selama penelitian dari $2(16,7 \%)$ sampai $10(83,3 \%)$.

Ada banyak faktor yang dapat mempengaruhi sehingga konseling yang diberikan belum dapat meningkatkan pengetahuan dan sikap ibu dalam menyusui. Salah satu kelemahan pada penelitian ini adalah yaitu tidak ada pengukuran pada semua variable / faktor yang mungkin berpengaruh terhadap pengetahuan dan sikap subjek. Faktorfaktor tersebut antara lain informasi yang diterima dari media 
masa, leaflet, poster tentang menyusui, kualifikasi petugas kesehatan / penolong persalinan dan lain-lain.

Hal lain yang dapat mempengaruhi adalah masih belum efektifnya konseling yang dilakukan karena belum dilakukan secara intensif. Menurut Ambawarwati,Ria, dkk (2013), konseling yang intensif perlu diberikan bagi ibu yang sedang menyusui. Konseling inipun perlu didukung dengan kemampuan konselor dalam menggabungkan pendapat para ahli dengan pengalaman menyusui ibu dari anak sebelumnya. Hal ini dapat membuat pengetahuan ibu meningkat lebih cepat.

Sikap ibu dipengaruhi oleh berbagai faktor, antara lain adat / kebiasaan/ kepercayaan menyusui didaerah masingmasing, pengalaman menyusui sebelumnya, pengetahuan tentang manfaat ASI dan kehamilan diinginkan atau tidak. Penyuluhan, siaran radio, televise /video, artikel di majalah /surat kabar dapat meningkatkan pengetahuan ibu, tetapi tidak selalu dapat mengubah apa yang dilakukan oleh ibu. Banyak ibu yang mempunyai masalah yang kadang tidak dapat diutarakan atau bahkan tidak dapat diselesaikan oleh dokter/petugas kesehatan. Faktor yang menyebabkan pemberian ASI eksklusif kurang dari 4 bulan pada kelompok perlakuan adalah ASI yang kurang (11,5 \%). Faktor lainnya ( bayi cengeng dan ibu bekerja) lebih banyak ditemukan pada kelompok kontrol (46,2\%). Hasil analisis statistik $\chi 2$ 
menunjukan tidak ada perbedaan yang bermakna tentang faktor yang mempengaruhi subjek untuk menyusui eksklusif 4 bulan antara kelompok perlakuan dengan kontrol $(P=0,780)$. Penelitian (Garbhani \& Padmiari, 2015) tentang faktor yang mempengaruhi keberhasilan pemberian ASI esklusif menunjukkan bahwa terdapat beberapa faktor yang menentukan keberhasilan ibu memberikan ASI ekslusif antara lain dukungan keluarga, dukungan tenaga kesehatan, dan promosi susu formula. Maraknya promosi susu formula pada ibu menyusui menyebabkan ibu merasa bahwa pemberian susu formula adalah hal yang lazim dan dapat menggantikan pemberian ASI. Keluarga dapat memberikan dukungan pemberian motivasi kepada ibu untuk terus menyusui bayinya, membantu ibu dalam menyelesaikan pekerjaan di rumah, membantu menyediakan makanan yang bergizi bagi ibu, serta menemani ibu sehingga tetap merasa tenang dan nyaman. Dukungan tenaga kesehatan merupakan salah satu faktor yang juga sangat berperan penting dalam keberhasilan ibu menyusui. Dukungan yang diberikan dapat berupa pemberian informasi yang benar tentang pemberian ASI, mengajarkan ibu cara menyusui yang benar, memberikan motivasi kepada ibu bahwa ibu dapat berhasil menyusui bayinya.

Penelitian yang dilakukan oleh (Lestari, 2015) tentang faktor yang mempengaruhi keberhasilan ibu dalam pemberian ASI ekslusif menyimpulkan bahwa keberhasilan ibu dalam 
memberikan ASI ekslusif dipengaruhi oleh faktor internal dan faktor eksternal. Faktor internalnya adalah dari ibu, seperti psikologis ibu (ibu tidak boleh mengalami gangguan psikologis dan ibu harus percaya diri dalam memberikan ASI), kondisi fisik ibu terutama kondisi putting ibu saat menyusui, waktu luang ibu untuk menyusui (dipengaruhi oleh apakah ibu bekerja atau tidak), ibu memahami manfaat memberikan ASI, ibu mendapatkan informasi tentang pemberian ASI dari berbagai sumber, termasuk dari keluarga dan penyuluhan dari berbagai pihak. Faktor eksternal yang mempengaruhi pemberian ASI antara lain perubahan sosial budaya, adanya penyuluhan kepada ibu dari tenaga kesehatan, adanya promosi susu formula dari pihak tertentu, serta dukungan dari keluarga terutama dari suami.

Pada penelitian ini, peneliti menemukan perbedaan yang bermakna tentang pertumbuhan antara kelompok perlakuan dengan kontrol. Berdasarkan penilaian KMS jumlah anak yang naik berat badannya lebih banyak pada kelompok perlakuan. Hal yang sama juga ditemukan pada persentase kenaikan berat badan dan panjang bandan. Kenaikan berat badan dan panjang badan lebih tinggi pada kelompok perlakuan dibandingkan kontrol.

Faktor-faktor yang mempengaruhi pertumbuhan dan perkembangan anak dibedakan atas faktor langsung dan tidak langsung. Faktor tidak langsung antara lain asuhan kepada ibu 
dan anak, ketahanan pangan keluarga, pelayanan kesehatan dan lingkungan. Faktor yang langsung mempengaruhi pertumbuhan anak yaitu kecukupan makanan dan keadaan kesehatan atau penyakit. Perlakuan konseling dalam penelitian ini sebagai mana tergambar pada kerangka konsep penelitian merupakan faktor yang tidak langsung berpengaruh terhadap pertumbuhan bayi.

Perbedaan kenaikan berat badan antara bayi yang menyusu eksklusif 4 bulan dan kurang dari 4 bulan seperti yang ditemukan dalam penelitian ini menunjukan bahwa faktor asupan turut menentukan pertumbuhan bayi. Komposisi zat gizi yang terdapat pada ASI merupakan komposisi yang sangat cocok untuk pertumbuhan bayi. Sumber kalori ASI terutama adalah lemak (3,5 - 4,5 \%) dan mudah diserap oleh bayi. Karbohidrat ASI adalah laktosa yang mudah terurai menjadi glukosa dan galaktosa. Kadar protein ASI 60\% adalah whein yang sangat mudah dicerna oleh bayi. Vitamin dan mineral yang terdapat pada ASI juga sangat sesuai untuk bayi (Pritasari,dkk. 2017).

\section{KESIMPULAN}

Kesimpulan dalam penelitian ini adalah tidak ada perbedaan bermakna tentang pengetahuan, sikap, dan kenaikan berat badan pada kelompok perlakuan dan kelompok control, terdapat perbedaan bermakna perilaku menyusui ekslusif pada kelompok perlakuan dan kelompok control, serta terdapat 


\section{DAFTAR PUSTAKA}

berdasarkan KMS dengan perilaku menyusu eksklusif.

Ambarwati,Ria,dkk. 2013. Pengaruh Konseling Laktasi Intensif terhadap Pemberian ASI Ekslusif sampai Tiga Bulan. Jurnal Gizi Indonesia.Volume 2 Nomor 1, Desember 2013. P-ISSN : 1858-4942 / E-ISSN : 2338-3119

Bappenas, 2011. Rencana Aksi Nasional Pangan Dan Gizi 20112015. Kementerian Perencanaan Pembangunan Nasional.

DPR-RI, 2012. Undang-Undang Republik Indonesia Nomor 18 Tahun 2012 Tentang Pangan

Hadi, H. (2004), Beban ganda masalah gizi dan implikasinya terhadap pembangunan Nasional : Pidato Pengukuhan Guru Besar pada Fakultas Kedokteran UGM, Yogyakarta.

Garbhani, I. H., \& Padmiari, E. (2015). Faktor- Faktor Yang Mempengaruhi Keberhasilan Pemberian ASI Eksksklusif di Wilayah Kerja Puskesmas I Denpasar Timur. Jurnal Virgin, 1(2), 177-190.

Kementerian Kesehatan,RI. (2018). Hasil Utama Riset Kesehatan Dasar. Jakarta. Indonesia

Kementerian Kesehatan R.I, 2010. Permenkes R.I Nomor 1995 tahun 2010 Tentang Standar Antropometri Penilaian Status Gizi Anak

Kementerian Kesehatan R.I, 2013. Permenkes R.I Nomor 75 tahun 2013 Tentang Angka Kecekupan Gizi yang dianjurkan bagi Bangsa Indonesia

Lensun, C.I.J., dkk., 2013. Pemanfaatan Sagu Baruk (Arenga Microcarpa) Dengan Ubi Jalar Ungu (Ipomoea Batatas) Dalam Pembuatan Mie Basah. Skripsi Fakultas Pertanian Universitas Samratulangi Manado.

Lestari, D. A. (2015). Faktor-faktor yang Mempengaruhi Keberhasilan Ibu dalam Pemberian ASI Eksklusif di BPS Pipin Heriyanti Kota Yogyakarta. UNISA Digital Library Repository. Retrieved from http://digilib.unisayogya.ac.id/1591/ 
Pritasari,dkk. 2017. Gizi dalam Daur Kehidupan. Pusat Pendidikan Sumber Daya Manusia Kesehatan. Jakarta

Rahmad,A.H. dan Miko, A. 2017. Peningkatan Pengetahuan Calon

Pengantin Melalui Konseling ASI Eksklusif di Aceh Besar Buletin Penelitian Kesehatan, Vol. 45, No. 4, Desember 2017: 249 - 256.

Sekretariat Wakil Presiden, RI. (2019). Strategi Nasional Percepatan Pencegahan Anak Kerdil (Stunting) Periode 2018-2024. Jakarta, Tim Nasional Percepatan Penanggulangan Kemiskinan. 